\title{
EVALUASI EFEKTIFITAS LAPORAN PEMAKAIAN DAN LEMBAR PERMINTAAN OBAT (LP-LPO) PUSKESMAS KOTA JAMBI
}

\section{Hisran Hamad Salmah}

Politeknik kesehatan Kementrian Kesehatan Jambi, Indonesia

Email: hisran1962@poltekkesjambi.ac.id

\begin{abstract}
Abstrak
Pentingnya data yang valid berarti tercapainya tujuan LP-LPO sebagai laporan pemakaian dan permintaan obat ke instalasi. Tujuan penilitian ini adalah untuk melihat bagaimana efektivitas laporan bulanan obat (LP-LPO) di puskesmas dengan mengukur indicator ketepatan permintaan, kesesuaian permintaan dan pemberian, ketepatan pemberian ke sub unit dan mengukur tingkat ketersediaan obat. Efektif disini berarti laporan yang baik berarti tersedianya sistem pelaporan obat yang efektif di puskesmas dan jaringannya. Metode: Desain penelitian adalah deskriptif kuantitatif dengan pendekatan observatif dan evaluative. Data permintaan dan pendistribusian obat dikumpulkan dari LPLPO Triwulan I,2,3 dan 4. Jumlah obat yang diobservasi 20 item obat. Pengamatan dilakukan terhadap kesesuaian pengisian data pada kolom permintaan dan pendistribusian LPLPO antara perhitungan seharusnya menurut teori dengan yang yang tertera dalam LP-LPO. Hasil: LP-LPO sudah dapat mengambarkan ketersediaan obat puskesmas. Rata-rata ktersediaan obat puskesmas 2,11 bulan yang termasuk kategori aman. Kesesuaian permintaan dan perhitungan, yang ajukan oleh puskesmas melalui LP-LPO sudah cukup baik, sesuai $61.5 \%$ sudah sesuai dengan perhitungan sesuai standar. Kesesuaian permintaan puskesmas yang diajukan melalui LP-LPO, 80.3\% sudah sesuai dengan pemberian yang diberikan oleh instalasi Farmasi.
\end{abstract}

Kata Kunci: LP-LPO; efektifitas; Kesesuaian permintaan, pemberian dan tingkat ketersediaan

\section{Abstract}

The importance of valid data means the achievement of lp-LPO objectives as a report on the use and demand of drugs to the installation. The purpose of this study is tosee how effective the monthly report of drugs (LP-LPO) in health centers by measuringindicators of demand accuracy, demand suitability and delivery, accuracy of administration to sub units and measuring the level of drug availability. Effective here means a good report means the availability of an effective drug reporting system in the health center and its network. Method: Research design is descriptively quantitative with an observative and evaluative approach. Data on drug demand and distribution were collected from LPLPO Quarters I, 2,3 and 4. The amount of drugs observed was 20 items of the drug. Observations are made on the suitability of filling data in the demand column and the distribution of LPLPO between calculations should be in theory with those stated in lp-LPO. Results: LP-LPO has been able to describe the availability of puskesmas drugs. The average availability of puskesmas drugs is 2.11 months

$\begin{array}{ll}\text { How to cite: } & \text { Salmah, H, H., (2022) Evaluasi Efektifitas Laporan Pemakaian dan Lembar Permintaan Obat (LP- } \\ & \text { LPO) Puskesmas Kota Jambi, Syntax Idea, 4(1), https://doi.org/10.36418/syntax-idea.v4i1.1713 } \\ \text { E-ISSN: } & \text { 2684-883X } \\ \text { Published by: } & \text { Ridwan Institute }\end{array}$


which belongs to the safe category. The suitability of requests and calculations, submitted by puskesmas through LP-LPO is good enough, according to $61.5 \%$ is in accordance with the calculation according to standards. The suitability of puskesmas request submitted through LP-LPO, $80.3 \%$ is in accordance with the grant given by the Pharmaceutical installation.

Keywords: LP-LPO; effectiveness; suitability of demand; granting and availability level

\section{Received: 2021-12-22; Accepted: 2022-01-05; Published: 2022-01-20}

\section{Pendahuluan}

Laporan Pemakaian dan Lembar Permintaan Obat (LPLPO) merupakan satusatunya laporan Obat bulanan yang wajib di buat puskesmas (Ditjen Yanfar DR, 2004). Laporan ini memiliki fungsi mencatat mutasi obat, sarana untuk permintaan obat ke Instalasi Farmasi dan pengeluaran obat ke sub unit. Selain itu LPLPO merupakan bukti pertanggung jawaban dari kepala puskesmas (Peraturan Menteri Kesehatan RI No 43 tahun 2019, 2019) atas penggunaan obat yang diberikan pemerintah yang jenis dan jumlahnya cukup besar (Jambi,2019). Berdasarkan survei awal yang dilakukan oleh peneliti, hingga saat ini puskesmas masih menggunakaan LPLPO di dalam laporan bulanan. Pada sampling beberapa obat indikator, permintaan yang tertulis di LP-LPO belum sesuai dengan perhitungan yang seharusnya, Hal yang sama pada jumlah obat yang disdistribusikan, ada perbedaan jumlah obat yang diminta sub unit dengan yang diberikan puskesmas. Dari 56 item obat yang di observasi, hanya 2 item atau 3.7\% terdapat kesesuaian antara permintaan dan yang didistribusikan. Tidak ditemukan buku rekapitulasi pemakaian puskesmas dan subunit. Demikian juga waktu pelaporan tidak lagi sesuai dengan waktu yang telah disepakati.

Penelitian ini juga telah dilakukan oleh penelitian terdahulu mengenai Pengelolaan obat di puskesmas merupakan hal yang sangat penting yang perlu di perhatikan, mengingat dengan pengelolaan yang tidak sesuai dengan prosedur yang tepat akan terjadi masalah tumpang tindih anggaran dan pemakaian yang tidak tepat guna (Gracia Dethan, 2018).

Data LP-LPO merupakan kompilasi dari dari puskesmas dan sub unit. Bagi Instalasi Farmasi kabupaten/Kota LP-LPO dimanfaatkan sebagai dokumen dan bukti pemberian obat ke puskesmas. Instalasi Farmasi Kabupaten/Kota dan Provinsi bahkan nasional menggunakan data pemakaian di LP-LPO untuk menghitung tingkat ketersediaan Obat Tingkat Kabupaten, Provinsi dan Nasional (RI, 29265BC). Permintaan yang diajukan puskesmas melalui LP-LPO berasal dari perhitungan stok optimum yang memuat data pemakaian, sisa stok, stok waktu kosong dan buffer stok. Idealnya jika data tersebut baik, maka permintaan puskesmas akan disetujui oleh instalasi farmasi, karena sudah dihitung sesuai dengan perhitungan menggunakan metode konsumsi atau morbiditas. Kenyataannya tidak semua permintaan tersebut disetujui. 
Hal yang sama terjadi pada distribusi obat dari puskesmas ke sub unit seperti pustu. Data LP-LPO yang digunakan adalah data kunjungan resep, data persediaan dan pemakaian. Pustu tidak akan kekurangan obat jika data LP-LPO yang menjadi sumber perhitungan tepat dan benar. Data yang dimanfaatkan puskesmas dari LP-LPO adalah persediaan, pemakaian, permintaan ke instalasi farmasi dan pemberian ke sub unit. Permintaan obat sub unit seperti pustu ke puskesmas sering tidak cocok karena keterbatasan tenaga yang pada umumnya dihitung bukan oleh tenaga kefarmasian. Oleh karena itu koreksi permintaan sub unit oleh tenaga pengelola obat puskesmas sangat penting agar menghindari terjadinya kekurangan obat. Puskesmas memiliki sumber daya yang lebih lengkap seperti sarana pengolah data computer. Efektifitas LP-LPO dapat diukur dari kesesuaian permintaan, pemberian yang dibuat puskesmas berdasarkan data yang ada di LP-LPO dengan perhitungan sesuai dengan teori. Jika permintaan yang diajukan mendekati perhitungan berarti data di LP-LPO sudah efektif. Demikian juga dengan distribusi ke pustu. Tujuan Penelitian untuk mempubikasikan naskah ke dalam Jurnal Bahana Kesehatan Masyarakat Poltekkes Kemenkes Jambi.

Permintaan obat puskesmas dilakukan dengan metode konsumsi, morbiditas dan gabungan keduanya (Depkes RI, 2016). Metode konsumsi didasarkan atas perhitungan stok optimum, menggunakan persamaan berikut :.

\section{$\mathrm{SO}=\mathbf{S K}+\mathbf{S W K}+\mathbf{S W T}+\mathbf{S P}$}

Sedangkan untuk menghitung permintaan obat dapat dilakukan dengan rumus :

\section{Permintaan $=$ SO - SS}

Keterangan :

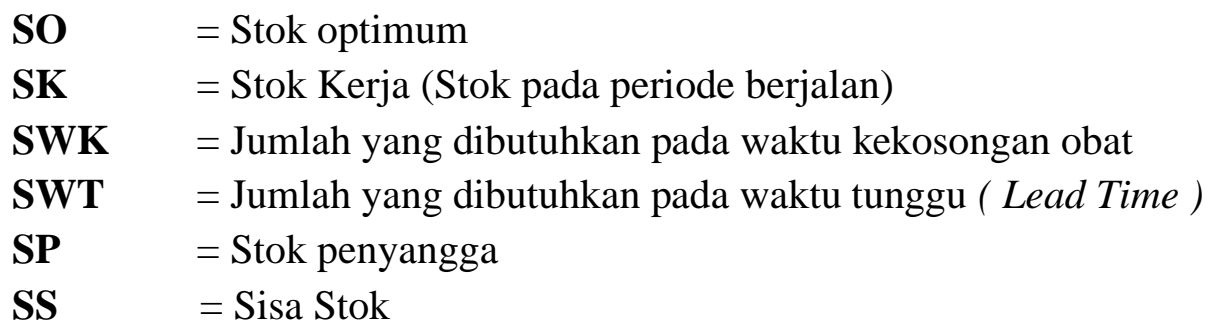

Periode permintaan biasanya disepakati antara puskesmas, instalasi farmasi dan dinas Kesehatan, umumnya di Provinsi Jambi, periode tersebut adalah setiap triwulan. SWK, SWT dan SP tergantung kondisi seperti jarak puskesmas dengan instalasi farmasi, Kesiapan Instalasi farmasi dan jadwal pengiriman laporan LP-LPO dari puskesmas ke Instalasi. Dalam perhitungan SO, variable SK ( stok kerja ) sangat penting. Rekapitulasi pemakaian baik dari puskesmas induk dan sub unit harus benar. Untuk itu register obat seperti buku harian pemakaian di apotek puskesmas dan sub unit tersedia dan diisi dengan benar sesuai kondisi yang sebenarnya. Disiplin petugas pengelola obat dalam mengisi register ini sangat penting. Oleh karena itu bantuan system pengolah data seperti computer sangat membantu. Saat ini di Dinas Kota Jambi telah tersedia aplikasi untuk mendukung pelaporan LP-LPO yaitu SILOLA (Antara Jambi), namun aplikasi itu lebih banyak diginakan untuk laporan pertanggungjawaban penggunaan dana obat di puskesmas dan instalasi farmasi. Di Sub unit pustu, poskesdes belum dapat digunakan. 
Permintaan yang diajukan puskemas ke Instalasi Farmasi akan diverifikasi oleh petugas Instalasi. Dengan kesiapan sumber daya dan teknologi, Instalasi akan menghitung ulang berdasarkan data yang dimiliki, kesesuaian permintaan puskesmas dengan pemberian instalasi menjadi indicator apakah data LP-LPO itu baik dan dapat digunakan dalam mengajukan permintaan obat sesuai dengan standar.

Permintaan obat yang diajukan oleh sub unit akan divalidasi dan dikoreksi oleh puskesmas. Metode pendistribusian obat ke sub unit dilakukan dengan metode floor stok atau stok alokasi (Ditjen Yanfar, 2004). Sumber data dari LP-LPO yang dibutuhkan adalah persediaan, kunjungan resep dan pemakaian. Data persediaan untuk menghitung persentasi obat yang didistribusikan, biasanya $85 \%$ dari persediaan obat di puskesmas, $15 \%$ sebagai buffer stok di Gudang penyimpanan puskesmas. Data kunjungan resep untuk menghitung alokasi maksimal/flavon setiap sub unit. Data pemakaian untuk menghitung rata-rata pemakaian/stok optimum. Dengan demikian sub unit tidak akan kekurangan atau kelebihan obat jika data tersebut di atas akurat.

Menurut Mardiasmo (Mardiasmo, 2018), Efektivitas adalah ukuran berhasil tidaknya pencapaian tujuan suatu organisasi mencapai tujuannya. Apabila suatu organisasi mencapai tujuan maka organisasi tersebut telah berjalan dengan efektif. Indikator efektivitas menggambarkan jangkauan akibat dan dampak (outcome) dari keluaran (Output) program dalam mencapai tujuan program. Semakin besar kontribusi output yang dihasilkan terhadap pencapaian tujuan atau sasaran yang ditentukan, maka semakin efektif proses kerja suatu unit organisasi. efektivitas merupakan hubungan antara keluaran dengan tujuan atau sasaran yang harus dicapai. Efektivitas LP-LPO dimaksudkan apakah data yang ada dalam LP-LPO dapat digunakan oleh puskesmas dalam mengajukan permintaan dan pendistribusian obat ke sub unit. Sebagai output LP-LPO adalah data permintaan obat ke instalasi farmasi dan data pemberian ke sub unit. Data permintaan dan pendistribusian dibandingkan dengan data seharusnya sesuai dengan standar perhitungan. Semakin tinggi kesesuaiannya maka semakin efektif LP-LPO.

$$
\text { Efektivitas }=\frac{\text { Iumlah Permintaan dalam } L P-L P O}{\text { Permintaan sesuai standar }} \times 100 \%
$$

Penilitian yang terkait adalah hasil penelitian (Chaira, Zaini, \& Augia, 2016) tentang Evaluasi Pengelolaan Obat pada Puskesmas di Kota Pariaman, menyatakan bahwa, ketepatan permintaan obat 2.28\%-24.47\%, ketepatan distribusi obat, $4.66 \%$ $35.59 \%$, Kedua hasil penilitian ini sangat jauh dari seharusnya jika dihitung dengan perhitungan menggunakan data di LP-LPO. Hasil ini belum sesuai dengan perhitungan yang sesungguhnya.

Penilitian ini diharapkan menjadi sumber informasi bagi Dinas Kesehatan Kota Jambi, Instalasi Farmasi dan yang utama adalah petugas pengelola obat di puskesmas untuk meningkatkan pengetahuan dan kinerja dalam membuat laporan LP-LPO yang berkualitas sehingga data yang ada di LP-LPO tersebut dapat dimanfaatkan secara optimal untuk membantu dalam mengajukan permintaan dan pendistribusian obat. 
Sehingga diharapkan tidak terjadi kekurangan atau kelebihan baik jenis dan jumlah obat di puskesmas dan sub unit.

\section{Metode Penelitian}

Desain penelitian adalah deskriptif kuantitatif dengan pendekatan observatif dan evaluative. Data permintaan dan pendistribusian obat dikumpulkan dari LPLPO Triwulan I,2,3 dan 4. Jumlah obat yang diobservasi 20 item obat. Pengamatan dilakukan terhadap kesesuaian pengisian data pada kolom permintaan dan pendistribusian LPLPO antara perhitungan seharusnya menurut teori dengan yang yang tertera dalam LP-LPO. Data wawancara dikumpulkan secara terstruktur dengan Kepala Puskesmas dan Apoteker/TTK (Tenaga Teknis Kefarmasian). Lokasi penelitian dilakukan di 20 Puskesmas Kota Jambi tahun 2019.

\section{Hasil dan Pembahasan}

Data pemakaian dalam LP-LPO, merupakan rekapitulasi pemakaian dari puskesmas induk dan seluruh sub unit seperti pustu, polindes, poskesdes, posyandu termasuk puskesmas keliling. Data pemakaian tersebut direkap dalam buku register rekap pemakaian. Dari 20 puskesmas, semua 100\% telah memiliki buku rekapitulasi pemakaian. Namun hanya 13 puskesmas atau 65\% yang menggunakan data tersebut untuk menghitung kebutuhan obat. Selebihnya mengunakan Sebagian atau tidak sama sekali. Hal yang sama ditemukan pada distribusi obat. Baru 3 puskesmas yang memiliki register distribusi obat dan dokumen perhitungan distribusi ke sub unit.

\section{Tabel 1}

\begin{tabular}{|c|c|c|c|}
\hline No & $\begin{array}{l}\text { Ketersediaan } \\
\text { register }\end{array}$ & $\begin{array}{l}\text { Jumlah } \\
\text { Puskesmas }\end{array}$ & $\%$ \\
\hline 1 & $\begin{array}{ll}\text { Buku } & \text { rekap } \\
\text { pemakaian } & \end{array}$ & 20 & 100 \\
\hline 2 & $\begin{array}{l}\text { Dokumen perhitungan } \\
\text { kebutuhan obat }\end{array}$ & 13 & 65 \\
\hline 3 & $\begin{array}{l}\text { Register } \quad \text { Rencana } \\
\text { distribusi }\end{array}$ & 3 & 15 \\
\hline 4 & $\begin{array}{l}\text { Dokumen Perhitungan } \\
\text { distribusi ke sub unit }\end{array}$ & 3 & 15 \\
\hline 5 & $\begin{array}{l}\text { Register kunjungan } \\
\text { resep }\end{array}$ & 20 & 100 \\
\hline & $\%$ Kesesuaian & & $59 \%$ \\
\hline
\end{tabular}

Namun yang sudah bagus adalah data kunjungan resep. Semua puskesmas telah memiliki register kunjungan resep dan rekapitulasi kunjungan resep. Data ini penting untuk menghitung nilai obat per resep dan per penduduk wilayah puskesmas. 
Tingkat ketersediaan obat dihitung berdasarkan rumusan stok akhir dibagi pemakaian rata-rata. Hasil yang didapat rata-rata obat di puskesmas masih cukup lebih dari 2 bulan terhitung dari stok akhir. Angka ini termasuk aman untuk tingkat ketersediaan, karena periode distribusi adalah 3 bulan/pertriwulan. Data di LP-LPO untuk menghitung tingkat ketersediaan adalah di Kolom stok akhir. Sementara pemakaian rata-rata adalah jumlah pemakaian 3 bulan di kolom pemakaian. Kriteria $<6$ bln: kurang, 6-18 bln: aman, > 18 bln: berlebih, jika dikonversikan dengan triwulan adalan : 1.5 bulan kurang, 1.5- 4.5 bulan aman, lebih 4.5 bulan berlebih

Tabel 2

\% Tingkat Kesesuaian Ketersediaan Obat Puskesmas

\begin{tabular}{llcc}
\hline No & $\begin{array}{l}\text { Rata-rata Tingkat } \\
\text { Ketersediaan ( bln) }\end{array}$ & Kondisi & $\begin{array}{c}\text { Jumlah } \\
\text { Puskesmas }\end{array}$ \\
\hline 1 & 1,1 bulan & kurang & 5 \\
2 & 2,5 bulan & aman & 15 \\
3 & Lebih 4,5 bln & berlebih & 0 \\
& $\begin{array}{l}\text { Rata rata puskesmas } \\
\text { \% Kesesuaian }\end{array}$ & & $75 \%$ \\
\hline
\end{tabular}

Telah baiknya pencatatan pemakaian obat memberi dampak positif pada ketersediaan obat, karena perhitungan menggunakan data pemakaian rata-rata. Tingkat ketersediaan tergolong aman, tercermin dari tidak ada keluhan masyarakat dalam berobat kepuskesmas seperti kekurangan obat dll. Namun masih ada beberapa puskesmas dalam posisi kurang, diantaranya Pakuan Baru 1.3 bulan, Simpang 4 Sipin yang hanya tidak sampai 2 bulan. Penilitian (Nursyandi, Mustofa, \& Hasanbasri, 2012), "ketersediaan Obat Essensial Pada sarana Kesehatan di Kabupaten Bangka Barat tahun 2012" menghasilkan tingkat ketersediaan 9.6 bulan, yang tergolong aman. Kemudian (I Carolien, A Fudholi, 2016), dengan judul penilitian “ Evaluasi ketersediaan obat sebelum dan sesudah implementasi JKN pada Puskesmas di Kabupaten Keerom Provinsi Papua tahun 2017", menghasilkan tingkat ketersediaan obat 90\% pada kondisi aman.

Kesesuaian permintaan puskesmas dengan perhitungan yang dilakukan sesuai metode, yaitu dengan menghitung stok optimum, kemudian dikurangi dengan sisa stok. Hasil yang didapat adalah rata-rata puskesmas sebesar 61.5\%. Persentase ketidaksesuaian cukup besar. Data LP-LPO yang digunakan adalah stok kerja yang merupakan pemakaian perperiode, stok waktu tunggu, yatu sejak LP-LPO di kirim hingga tanggal LP-LPO pemberian obat. 


\section{Tabel 3}

\begin{tabular}{llcc}
\multicolumn{3}{c}{$\%$} & Kesesuaian Permintaan dengan Perhitungan Obat Puskesmas \\
\hline No & Kriteria & $\begin{array}{c}\text { Kesesuaian } \\
\text { permintaan (\%) }\end{array}$ & $\begin{array}{l}\text { Jumlah } \\
\text { Puskesmas }\end{array}$ \\
\hline 1 & Sesuai & $64-74$ & 11 \\
2 & Kurang sesuai & $54-63$ & 6 \\
3 & Tidak sesuai & $44-54$ & 3 \\
& Rata rata puskesmas & 61,6 & 20 \\
& \% kesesuaian & & $61.5 \%$ \\
\hline
\end{tabular}

Kesesuaian dengan perhitungan memberi hasil yang cukup dibandingkan dengan permintaan. Rata-rata baru tercapai $61.5 \%$. Stok optimum pada LP-LPO yang diisi oleh puskesmas, setelah di hitung sesuai aturan memberi hasil yang berbeda. Hasil penilitian (Chaira et al., 2016) dengan judul penilitian "Evaluasi Pengelolaan Obat pada puskesmas di Kota Pariaman" menghasilkan rata -rata ketepatan permintaan obat puskesmas tertinggi sebesar $24.47 \%$ ketepatan permintaan obat seluruh Puskesmas jauh dibawah standar yang ditetapkan yaitu $100 \%$. Permasalahan ini terjadi karena dalam melakukan permintaan dalam setiap periode distribusi pengelola obat puskesmas tidak memperhitungkan stok optimum , artinya pengelola obat tidak memperhitungkan waktu tunggu dan waktu kekosongan obat, hal ini mengakibatkan ketersediaan obat di puskesmas ada yang berlebih dan ada yang kurang

Kesesuaian Permintaan dan pemberian Instalasi Farmasi, Permintaan puskesmas yang diajukan ke instalasi dengan LP-LPO, akan di analisis lagi oleh Instalasi. Instalasi Farmasi akan menetapkan alokasi per puskesmas sesuai dengan persediaan yang ada. Aturan pemberian Instalasi Farmasi adalah: Jika permintaan melebihi alokasi maka akan diberikan sesuai alokasi. Jika permintaan kurang dari alokasi maka diberikan sesuai permintaan puskesmas. Dengan aturan ini, permintaan puskesmas sangat penting. Dari data yang ada kesesuaian antara permintaan puskesmas dengan pemberian instalasi sudah baik, yaitu rata-rata $81.3 \%$. Ini menunjukkan bahwa data permintaan yang ada di LP-LPO puskesmas sudah menunjukkan data yang sebenarnya.

Tabel 4

\% Kesesuaian Permintaan Puskesmas Dengan Dan Pemberian Oleh Instalasi Farmasi

\begin{tabular}{llcc}
\hline No & Kriteria & $\begin{array}{c}\text { Kesesuaian } \\
\text { permintaan (\%) }\end{array}$ & $\begin{array}{l}\text { Jumlah } \\
\text { Puskesmas }\end{array}$ \\
\hline 1 & Sesuai & $80-93$ & 11 \\
2 & Kurang sesuai & $67-79$ & 7 \\
3 & Tidak sesuai & $54-66$ & 2 \\
& Rata rata puskesmas & 81,3 & 20 \\
& \% Kesesuaian & & $81.3 \%$ \\
\hline
\end{tabular}

Dibandingkan dengan perhitungan, kesesuaian dengan perberian instalasi lebih baik nilainya. Instalasi menghitung dengan data yang sama dari puskesmas, namum 
karena petugas yang mengerjakannya lebih baik didukung oleh ketersediaan computer pengolah data sehingga beberapa permintaan puskesmas di koreksi oleh instalasi. Rata pencapaian sebesar $81.3 \%$.

Menurut. (Nurniati, 2016) dalam penilitian tentang Studi Tentang Pengelolaan obat di Puskesmas Burangga Kabupaten Wakatobi tahun 2016, memberi hasil yang berbeda. Kesimpulan dari penelitian ini, terkait pendistribusian serta pencatatan dan pelaporan sudah sesuai standar pengelolaan obat di Puskesmas. Tetapi perencanaan, pengadaan, dan penyimpanan obat belum sesuai dengan pedoman pengelolaan obat yang ada.

Sudibyo Supardi (Herman, Susyanti, Raharni, \& Supardi, 2012), meneliti “ Evaluasi Peran Apoteker berdasarkan Pedoman Pelayanan Kefarmasian di Puskesmas “ diantaranya menyimpulkan bahwa Permasalahan yang terkait dengan apoteker di puskesmas adalah ketersediaan dan jumlah tidak sesuai dengan beban kerjanya, sehingga pelayanan kefarmasian belum berjalan baik akibat keterbatasan waktu dan tenaga. Juga ada apoteker merasa kurang mampu dalam memberikan informasi obat kepada tenaga kesehatan lain, khususnya dokter spesialis di beberapa puskesmas perawatan, sehingga masih diperlukan pembinaan dan pelatihan.

Kesesuaian Pendistribusian dengan Perhitungan, adalah kegiatan distribusi obat oleh puskesmas ke sub unit seperti puskesmas pembantu, pos kesehatan desa, Polindes dan pusling dan dalam porsi yang besar kepada apotek puskesmas. Sistem pendistribusian umumnya mengguinakan system floor stock atau stok alokasi (Kemenkes, 1384), yaitu puskesmas memberikan sejumlah paket obat untuk kebutuhan satu bulan atau triwulan. Perhitungan jumlah obat yang didistribusikan mempertimbangkan, jumlah kunjungan, pemakaian dan sisa stok dari sub unit. Hasil untuk 20 puskesmas sebagai berikut:

Tabel 5

$\%$ Kesesuaian Pendistribusian dengan Perhitungan

\begin{tabular}{llcc}
\hline No & Kriteria & $\begin{array}{l}\text { Kesesuaian } \\
\text { Pendistribusian (\%) }\end{array}$ & $\begin{array}{l}\text { Jumlah } \\
\text { Puskesmas }\end{array}$ \\
\hline 1. & Sesuai & $63-76$ & 9 \\
2. & Kurang sesuai & $49-62$ & 9 \\
3. & Tidak sesuai & $35-48$ & 2 \\
& Rata rata puskesmas & 60.5 & 20 \\
& \% kesesuaian & & $35 \%$ \\
\hline
\end{tabular}

Dari rata-rata kesesuaian $60.5 \%$ di kategorikan kurang sesuai. Kurang sesuai disini bisa berlebih atau kurang dari perhitungan yang mempertimbangkan data LP-LPO sub unit puskesmas. Hanya 9 puskesmas dengan kategori sesuai, 9 puskesmas kurang sesuai dan 2 puskesmas tidak sesuai. Ketidaksesuaian ini menyebabkan bisa mengganggu pelayanan Kesehatan di sub unit. 


\section{Kesimpulan}

Dari hasil penilitian dapat di simpulkan sebagai berikut mutu LP-LPO puskesmas di Kota Jambi sudah baik yang ditandai pencapaian indicator pengelolaan obat yang baik, namun belum didukung oleh tenaga sesuai standar. Ketersediaan tenaga kefarmasian belum mencukupi kebutuhan untuk melaksanakan penccatatan dan pelaporan LP-LPO. Rasio apoteker 0.4, TTK 2.75. Namun kebijakan Kepala Dinas Kesehatan tentang Apoteker supervise dapat mengatasi kekurangan tenaga tersebut. Metode pengelolaan obat belum dilaksanakan sepenuhnya pencapaian baru $56.2 \%$, demikian juga dengan sarana pencatatan sudah mencapai 70.6\%, Tingkat ketersediaan, LP-LPO sudah dapat mengambarkan ketersediaan obat puskesmas. Rata ketersediaan obat puskesmas 2.11 bulan yang termasuk kategori aman, Kesesuaian permintaan dan perhitungan, Permintaan yang diajukan oleh puskesmas melalui LP-LPO sudah cukup baik, sesuai $61.5 \%$ sudah sesuai dengan perhitungan sesuai standar, Kesesuaian permintaan dengan Pemberian, Permintaan puskesmas yang diajukan melalui LP-LPO, 80.3\% sudah sesuai dengan pemberian yang diberikan oleh instalasi Farmasi.

\section{BIBLIOGRAFI}

Antara Jambi. (2019). Kota Jambi optimalkan aplikasi "E-Silola" tentang data persediaan obat.

Chaira, Syukriati, Zaini, Erizal, \& Augia, Trisfa. (2016). Evaluasi Pengelolaan Obat pada Puskesmas di Kota Pariaman. Jurnal Sains Farmasi \& Klinis, 3(1), 35. Google Scholar

Depkes RI. (2016). Peraturan Menteri Kesehatan RI Nomor 74 tahun 2016 tentang Standar Pelayanan Kefarmasian di Puskesmas.

Ditjen Yanfar, Depkes RI. (2004). Pedoman Pengelolaan Obat Publik dan Perbekalan Kesehatan di Puskesmas.

Ditjen Yanfar DR. (2004). Pedoman Pengelolaan Obat Publik dan Perbekalan Kesehatan di Puskesmas.

Gracia Dethan, Ayu. (2018). Kualitas Sistem Pengelolaan Obat Di Puskesmas Bakunase Tahun 2017. Poltekkes Kemenkes Kupang. Google Scholar

Herman, Max, Susyanti, Andi Leny, Raharni, Raharni, \& Supardi, Sudibyo. (2012).

Evaluasi Peran Apoteker Berdasarkan Pedoman Pelayanan Kefarmasian Di Puskesmas. Media Penelitian Dan Pengembangan Kesehatan, 22(4), 190-198. Google Scholar

I Carolien, A Fudholi, D. Endarti. (2016). Evaluasi Ketersediaan Obat Sebelum dan Sesudah Implementasi JKN pada Puskesmas Di Kabupaten Keerom Provinsi 
Hisran Hamad Salmah

Papua. Google Scholar

Jambi, Dinas Kesehatan Kota. (2019). Profil Dinas Kesehatan Kota Jambi tahun 2019.

Kemenkes, Ditjen Yanfa. (1384). Petunjuk Teknis Permenkes 74 tahun 2016.

Mardiasmo. (2018). Akuntasi Sektor Publik. Jakarta.

Nurniati. (2016). Studi tentang. 1-9.

Nursyandi, Achmad, Mustofa, Mustofa, \& Hasanbasri, Mubasysyir. (2012).

Ketersediaan obat esensial pada sarana kesehatan di Kabupaten Bangka Barat.

Jurnal Kebijakan Kesehatan Indonesia : JKKI, 1(3), 125-133. Google Scholar

Peraturan Menteri Kesehatan RI No 43 tahun 2019. (2019). Peraturan Menteri Kesehatan RI No 43 tahun 2019 tentang Puskesmas. Peraturan Menteri Kesehatan RI No 43 Tahun 2019 Tentang Puskesmas, Nomor 65(879), 2004-2006.

RI, Direktorat Bina Obat Publik dan Perbekalan Kesehatan Direktorat Bina Kefarmasian dan Alat Kesehatan Kemnterian Kesehatan. (29265BC). Pedoman Supervisi dan Evaluasi Obat Publik dan Perbekalan Kesehatan.

\section{Copyright holder:}

Hisran Hamad Salmah (2022)

\section{First publication right:}

Syntax Idea

This article is licensed under:

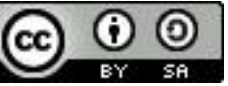

